\title{
PENINGKATAN KEMAMPUAN MENGAJAR GURU MELALUI TEKNIK SUPERVISI KELAS
}

\author{
Bambang Herry Iriantoro \\ Dinas Pendidikan Kecamatan Loceret, Jl Raya Kediri 171 Loceret, Nganjuk. \\ Email : bambangherry36@yahoo.com
}

\begin{abstract}
Improvement of Teaching Ability through The Class Supervision Technique. This study aims to improve the teaching skills of primary school teachers in learning through the implementation of supervision. The study was conducted in Gugus 3 Loceret the District Nganjuk with the design school action research, conducted in two cycles. The survey results revealed that the ability of teachers to teach elementary school could be improved through classroom supervision techniques. Improving the ability of teachers to teach is demonstrated by (a) increasing the ability to manage a class, (b) increasing the ability to use learning strategies, (c) increase the capacity to manage the interaction of classes, (d) an increase in the ability to help develop positive attitudes of students and (e) an increase in the ability to execute evaluation process and learning outcomes.
\end{abstract}

Keywords: teaching skills, classroom supervision techniques

\begin{abstract}
Abstrak: Peningkatan Kemampuan Mengajar Guru melalui Teknik Supervisi Kelas. Penelitian ini bertujuan untuk meningkatkan kemampuan mengajar guru SD dalam pembelajaran melalui pelaksanaan supervisi. Penelitian dilakukan Gugus 3 Kecamatan Loceret Kabupaten Nganjuk dengan rancangan penelitian tindakan sekolah, dilaksanakan dalam 2 siklus. Hasil penelitian diketahui bahwa kemampuan mengajar guru SD dapat ditingkatkan melalui teknik supervisi kelas. Peningkatan kemampuan mengajar guru tersebut ditunjukkan oleh (a) peningkatan kemampuan mengelola kelas, (b) peningkatan kemampuan menggunakan strategi pembelajaran, (c) peningkatan kemampuan mengelola interaksi kelas, (d) peningkatan kemampuan membantu mengembangkan sikap positif siswa dan (e) peningkatan kemampuan melaksanakan evaluasi proses dan hasil belajar.
\end{abstract}

Kata Kunci : kemampuan mengajar, teknik supervisi kelas

Keberhasilan pembelajaran dipengaruhi oleh beberapa aspek, antara lain kurikulum, guru, siswa, media, buku sumber. Selain sebagai penentu keberhasilan pembelajaran, guru juga merupakan ujung tombak kelancaran proses belajar mengajar terutama di Sekolah Dasar (SD). Keberhasilan guru mengajar juga dipengaruhi oleh peran kepala sekolah dalam pembinaan guru termasuk pembinaan kemampuan guru dalam mengajar.

Tugas kepala sekolah selain sebagai manager, administrator juga sebagai supervisor. Agar tugas-tugas tersebut dapat dilaksanakan dengan baik, perlu ada pembinaan secara berkelanjutan. Tugas kepala sekolah yang paling perlu mendapat penekanan adalah tugas sebagai supervisor (Hariwung, 1981). Supervisi diperlukan dalam proses pembelajaran berdasarkan dua hal, yaitu: (1) perkembangan kurikulum yang merupakan gejala kemajuan pendidikan, (2) perkembangan personel yang merupakan upaya terus-menerus dalam suatu organisasi. Fungsi kepala sekolah sebagai supervisor adalah memberikan layanan kepada guru dalam upaya meningkatkan kemampuan dan kualitas profesionalnya. Supervisi yang dilakukan 
kepala sekolah, antara lain untuk meningkatkan kemampuan guru dalam kegiatan belajar mengajar, sehingga dapat memenuhi misi pengajaran yang diembannya.

Masih banyak guru sekolah dasar di Gugus 3 Kecamatan Loceret Kabupaten Nganjuk yang masih belum memiliki kemampuan mengajar sesuai dengan kompetensi profesional guru (Imron, 1999). Salah satu penyebab belum maksimalnya tugas mengajar guru adalah kurang sesuainya teknik supervisi yang diterapkan kepala sekolah. Secara umum persoalan tersebut meliputi: pelaksanaan supervisi yang masih menggunakan jalur satu arah, yaitu dari kepala sekolah sebagai atasan terhadap guru sebagai bawahan; sulitnya memadukan keinginan antara kepala sekolah dan guru tentang teknik supervisi yang harus digunakan; alokasi waktu pelaksanaan supervisi yang amat terbatas; dan supervisi sering kali dilakukan atas inisiatif dan keinginan kepala sekolah semata.

Supervisi pada suatu sekolah merupakan tanggung jawab kepala sekolah. Pada lingkup yang lebih luas, tugas supervisi menjadi tanggung jawab seorang pengawas. Namun jika peran kepala sekolah belum maksimal, maka tugas supervisi dapat diperkuat oleh pengawas.

Ada sejumlah teknik supervisi yang dikemukakan oleh para ahli. Teknik supervisi diharapkan mampu memberi dampak positif terhadap pembentukan sikap dan kemampuan guru. Supervisi sebagai kegiatan pembinaan guru dapat dilakukan melalui teknik individual: supervisor mengamati kegiatan pembelajaran yang sedang berlangsung (classroom observasion), eksperimentasi kelas (class experiment), guru mengunjungi guru lain pada saat pembelajaran berlangsung (class intervisitation), supervisor melakukan percakapan pribadi dengan guru (individual conferency), seleksi mata pelajaran (selected of materials for teaching), dan evaluasi diri (self evaluation).

Melakukan supervisi tidak sekedar bermakna melihat atau mengamati aktivitas guru, tetapi perlu juga melibatkan semua indera, logika, strategi, dan berbagai instrumen.Beberapa hal yang perlu dicatat oleh supervisor adalah: (a) suasana kelas, (b) cara memulai dan menutup pelajaran, (c) kecocokan metode yang digunakan, (d) penggunaan media, (e) cara mengaktifkan siswa, (f) tugas berstruktur yang diberikan untuk menumbuhkan hasil pengiring, (g) perkembangan afeksi siswa, (h) pemahaman kognisi siswa, dan (i) kemampuan psikomotor siswa. Untuk melakukan supervisi pada suatu pertemuan supervisor membutuhkan satu sampai dengan tiga jam berturut-turut (Pidarta, 1999). Alasan penting dipilihnya teknik supervisi kelas untuk melakukan supervisi guru adalah: (a) yang diamati keseluruhan proses belajar mengajar dalam satu pertemuan, dan bukan sampel-sampel PBM yang diinginkan, (b) untuk mengetahui aktivitas belajar mengajar secara keseluruhan, bukan untuk mengetahui aktivitas-aktivitas khusus, (c) supervisor tidak boleh berpartisipasi dalam PBM, dan (d) dilakukan pada waktu pembelajaran sedang berlangsung.

Supervisor adalah orang yang melakukan aktivitas supervisi dan langsung berhubungan dengan guru khususnya dalam rangka peningkatan proses pembelajaran agar lebih efektif. Di tingkat sekolah yang menjadi supervisor adalah kepala sekolah. Mengacu pada Peraturan Menteri Pendidikan Nasional Nomor 12 Tahun 2007 tentang Standar Pengawas Sekolah, menyebutkan bahwa kepala sekolah sebagai supervisor diantaranya yaitu membantu guru dalam perencanaan, pelaksanaan, dan evaluasi proses pembelajaran. Peran dalam perencanaan dan pelaksanan pembelajaran, yaitu membina unsurunsur yang berkaitan dengan pembinaan terhadap guru dalam proses pembelajaran diantaranya yaitu menumbuhkan motivasi kerja pada guru, membimbing guru dalam menyusun silabus tiap mata pelajaran yang berlandaskan standar isi, standar kompetensi, kompetensi dasar, dan prinsipprinsip pengembangan kurikulum tingkat satuan pendidikan, membimbing guru dalam memilih dan menggunakan metode atau teknik pembelajaran atau bimbingan yang dapat mengembangkan berbagai potensi siswa, membimbing guru dalam menyusun rencana program pembelajaran, membimbing guru dalam kegiatan pembelajaran di kelas, membimbing guru dalam mengelola, merawat, mengembangkan, dan menggunakan media pendidikan dan fasilitas pembelajaran, memotivasi guru untuk memanfaatkan teknologi informasi dalam pembelajaran. Peran dalam kegiatan evaluasi proses pembelajaran, yaitu membina guru dalam mengevaluasi proses pembelajaran yang 
telah dilaksanakan diantaranya yaitu membina guru menyusun kriteria atau indikator keberhasilan pendidikan dan pembelajaran, membimbing guru dalam menentukan aspek-aspek yang penting dinilai dalam pembelajaran, membimbing guru dalam memanfaatkan hasil penilaian untuk perbaikan mutu pendidikan dan pembelajaran. Peran tersebut perlu dilaksanakan mengingat kepala sekolah juga merupakan calon pengawas sekolah. Peran kepala sekolah sebagai supervisor dalam memberikan bantuan yaitu meliputi bantuan dalam merencanakan, melaksanakan, mengevaluasi proses pembelajaran.

Secara profesional, dalam proses pembelajaran guru memiliki tugas utama sebagai berikut: (1) menyusun program pengajaran, (2) melaksanakan program pengajaran, (3) melakukan evaluasi, (4) melakukan analisis hasil evaluasi, dan(5) melakukan program perbaikan dan pengayaan. Di samping itu, untuk menunjang keberhasilan profesionalnya, guru juga dituntut cakap dalam aktivitas sosial dalam berinteraksi dengan lingkungannya.

Proses pembelajaran merupakan tahap pelaksanaan yang telah direncanakan oleh guru (Nawawi,1981).Kegiatan inimenuntutkemampuan guru untuk menciptakan dan menumbuhkan kegiatan belajar siswa sesuai dengan rencana. Guru juga harus menganalisa tingkat pemahaman siswa terhadap materi pembelajaran yang disampaikan, ketepatan metode pembelajaran yang digunakan, sehingga tujuan pembelajaran dapat tercapai. Untuk melaksanakan tugas, guru dituntut memiliki kemampuan mengajar. Kurangnya kemampuan mengajar akan mempengaruhi kinerja guru dalam melaksanakan tugas.

Kemampuan pertama yang harus dimiliki guru adalah kemampuan merencanakan pembelajaran. Mengajar merupakan pelaksanaan rencana pembelajaran yang telah dibuat sebelumnya. Semakin mampu merencanakan pengajaran, seorang guru akan semakin mudah mengajar di kelas (Ghafir, 1983; Sudjana, 1984).

Kemampuan mengajar sebagai kemampuan kedua yang harus dimiliki oleh guru, berkenaan dengan bagaimana guru menciptakan suatu sistem pengajaran sesuai dengan yang telah direncanakan sebelumnya. Kemampuan mengajar menunjuk pada kemampuan guru menggunakan alat penilaian yang telah disusun, materi, metode, media dan sumber pengajaran yang telah dipilih, dan langkah-langkah KBM yang telah disusunnya dalam PBM.

\section{METODE}

Penelitian ini merupakan Penelitian Tindakan Sekolah (PTS) di Sekolah Dasar yang ada di Gugus 3 Kecamatan Loceret Kabupaten Nganjuk dengan jumlah sebanyak 10 Sekolah Dasar. Penelitian ini melibatkan masing-masing sekolah 1 orang guru sebagai subyek penelitian dan masing-masing sekolah 1 orang kepala sekolah sebagai kolaborator. Jenis penelitian dirancang dengan menggunakan Penelitian Tindakan Sekolah (PTS) atau School Action Research (SAR). Penelitian tindakan ini memiliki karakteristik partisipatif, yang melibatkan para pelaksana program yang akan diperbaiki. Penelitian ini juga bersifat kolaboratif, artinya dikerjakan bersama-sama peneliti (pengawas sekolah) dan praktisi (pelaksana program, yaitu kepala sekolah dan guru) sejak dari perumusan masalah sampai dengan penyusunan laporan. Penelitian ini difokuskan pada penyempurnaan kegiatan supervisi kelas yang dilakukan oleh kepala sekolah terhadap guru dalam meningkatkan kemampuan mengajar.

Penelitian ini dilakukan dalam 2 siklus untuk tiap-tiap sekolah. Teknik pengumpulan data menggunakan observasi dan wawancara. Observasi digunakan untuk memperoleh data dan fakta tentang kemampuan guru dalam merencanakan dan melaksanakan proses pembelajaran di kelas. Wawancara secara tidak terstruktur digunakan untuk memperoleh data tentang pendapat guru atas pengalamannya dalam merencanakan dan melakanakan pengajaran. Analisis data dilakukan dengan menggunakan analisis kualitatif dan kualitatif. Analisis data kualitatif dilakukan melalui 3 tahap, yaitu reduksi data, paparan data, dan penyimpulan. Analisis data kuantitatif dilakukan secara deskriptif.

\section{HASIL DAN PEMBAHASAN}

\section{Hasil}

Siklus I. Pada tahap perencanaan, kepala sekolah dan guru diberi penjelasan tentang konsep supervisi kelas beserta instrumen-instrumen yang telah disiapkan, dan diberi arahan tentang hal- 
hal yang harus dipersiapkan oleh kepala sekolah dan guru. Pelaksanaan tindakan dilakukan sesuai jadwal yang disepakati antara peneliti dan sekolah yang menjadi sasaran penelitian. Secara ringkas hasil observasi dapat dilihat pada Tabel 1 .

Berdasarkan hasil refleksi diketahui bahwa, kemampuan guru dalam proses pembelajaran mencapai kategori yang cukup baik dari segi pengetahuan, keterampilan dan sikap. Guru telah mampu memotivasi murid untuk lebih giat belajar, guru telah menguasai mata pelajaran yang diajarkan, mampu memilih dan menerapkan berbagai metode dan media pembelajaran secara lebih tepat, memahami aspek kejiwaan dan psikologi belajar murid. Guru mampu mengajar dengan baik, memiliki kemampuan berkomunikasi, menggunakan bahasa, memilih dan menerapkan metode dan alat sesuai dengan situasi riil, keterampilan berinteraksi, bertanya dan menyusun pertanyaan sesuai dengan kemampuan sasaran didik.
Siklus II merupakan tindak lanjut dari siklus I. Kegiatan yang dilaksanakan pada siklus II sama dengan kegiatan pada siklus I, yaitu menyusun rencana tindakan, mengkondisikan subyek penelitian (kepala sekolah sebagai supervisor dan guru sebagai pihak yang akan disupervisi). Pada tahap ini juga dijelaskan tentang konsep supervisi kelas dan instrumen-instrumen yang digunakan, serta hal-hal yang perlu disiapkan oleh kepala sekolah dan guru. Pelaksanaan tindakan dilakukan di 10 sekolah sebagaimana pada siklus I. Secara singkat, hasil tindakan dapat dilihat pada Tabel 2.

Berdasarkan hasil refleksi diketahui bahwa komitmen dari kepala sekolah dalam upaya perbaikan dan peningkatan keterampilan mensupervisi guru harus terus dipertahankan dan dikembangkan sesuai dengan situasi dan kondisi sekolah. Untuk lebih memperjelas perkembangan hasil penelitian dari siklus I ke siklus IIdapat diperiksa pada Tabel 3.

Tabel 1: Data Hasil Pengamatan Kemampuan Guru

\begin{tabular}{|c|c|c|c|c|c|c|c|c|}
\hline \multirow{2}{*}{ No. } & \multirow{2}{*}{ Nama Guru } & \multirow{2}{*}{ Nama Sekolah } & \multicolumn{5}{|c|}{ Hasil Pengamatan } & \multirow{2}{*}{ Rerata } \\
\hline & & & A & $\mathrm{B}$ & $\mathrm{C}$ & $\mathrm{D}$ & $\mathrm{E}$ & \\
\hline 1 & HS & SDN Karangsono & 2,67 & 2,75 & 2,80 & 3,80 & 3,50 & 2,75 \\
\hline 2 & SAW & SDN Genjeng 1 & 3,00 & 2,25 & 2,80 & 4,00 & 4,00 & 3,21 \\
\hline 3 & YH & SDN Genjeng 3 & 3,00 & 2,50 & 3,20 & 3,60 & 4,00 & 3,26 \\
\hline 4 & $\mathrm{Sp}$ & SDN Godean 1 & 2,33 & 2,25 & 3,00 & 3,60 & 4,00 & 3,04 \\
\hline 5 & MTU & SDN Godean 2 & 3,67 & 2,75 & 3,20 & 3,60 & 4,00 & 3,44 \\
\hline 6 & LH & SDN Ngepeh 1 & 2,67 & 2,25 & 2,60 & 4,00 & 4,00 & 3,10 \\
\hline 7 & EY & SDN Ngepeh 2 & 3,33 & 2,25 & 2,80 & 3,80 & 4,00 & 3,24 \\
\hline 8 & $\mathrm{Sk}$ & SDN Ngepeh 3 & 3,00 & 2,75 & 3,20 & 3,60 & 3,00 & 3,11 \\
\hline 9 & DW & SDN Ngepeh 4 & 2,33 & 2,75 & 3,00 & 3,40 & 3,00 & 2,90 \\
\hline 10 & YA & SDI As-Syafi'ah & 3,67 & 2,50 & 3,40 & 4,00 & 4,00 & 3,51 \\
\hline \multicolumn{3}{|c|}{ Rerata } & 2,97 & 2,50 & 3,00 & 3,74 & 3,75 & 3,16 \\
\hline
\end{tabular}

\section{Keterangan:}

$\mathrm{A}=$ Kemampuan Mengelola Kelas, Waktu, dan Fasilitas Belajar

$\mathrm{B}=$ Kemampuan Menggunakan Strategi Pembelajaran

$\mathrm{C}=$ Kemampuan Mengelola Interaksi Kelas

$\mathrm{D}=$ Kemampuan Membantu Mengembangkan Sikap Positif Siswa Terhadap Belajar

$\mathrm{E}=$ Kemampuan Melaksanakan Evaluasi Proses dan Hasil Belajar 
Tabel 2: Data Hasil Pengamatan Kemampuan Guru

\begin{tabular}{|c|c|c|c|c|c|c|c|c|}
\hline \multirow{2}{*}{ No. } & \multirow{2}{*}{ Nama Guru } & \multirow{2}{*}{ Nama Sekolah } & \multicolumn{5}{|c|}{ Hasil Pengamatan } & \multirow{2}{*}{ Rerata } \\
\hline & & & A & B & $\mathrm{C}$ & $\mathrm{D}$ & $\mathrm{E}$ & \\
\hline 1 & $\mathrm{HS}$ & SDN Karangsono & 4,33 & 4,50 & 4,60 & 5,00 & 4,50 & 4,50 \\
\hline 2 & SAW & SDN Genjeng 1 & 4,00 & 4,25 & 4,20 & 4,80 & 5,00 & 4,45 \\
\hline 3 & $\mathrm{YH}$ & SDN Genjeng 3 & 4,67 & 4,25 & 5,00 & 5,00 & 5,00 & 4,78 \\
\hline 4 & $\mathrm{Sp}$ & SDN Godean 1 & 4,67 & 4,25 & 4,40 & 4,40 & 5,00 & 4,54 \\
\hline 5 & MTU & SDN Godean 2 & 4,33 & 4,50 & 4,60 & 4,80 & 5,00 & 4,65 \\
\hline 6 & $\mathrm{LH}$ & SDN Ngepeh 1 & 4,00 & 4,25 & 4,40 & 4,60 & 5,00 & 4,45 \\
\hline 7 & EY & SDN Ngepeh 2 & 4,67 & 4,25 & 4,40 & 5,00 & 5,00 & 4,66 \\
\hline 8 & $\mathrm{Sk}$ & SDN Ngepeh 3 & 4,67 & 4,25 & 4,60 & 5,00 & 4,50 & 4,60 \\
\hline 9 & DW & SDN Ngepeh 4 & 4,67 & 4,50 & 4,40 & 4,80 & 4,50 & 4,57 \\
\hline 10 & YA & SDI As-Syafi'ah & 4,33 & 4,50 & 4,80 & 4,80 & 5,00 & 4,69 \\
\hline \multicolumn{3}{|c|}{ Rerata } & 4,43 & 4,35 & 4,54 & 4,82 & 4,85 & 4,59 \\
\hline
\end{tabular}

\section{Keterangan:}

A= Kemampuan Mengelola Kelas, Waktu, dan Fasilitas Belajar

$\mathrm{B}=$ Kemampuan Menggunakan Strategi Pembelajaran

$\mathrm{C}=$ Kemampuan Mengelola Interaksi Kelas

$\mathrm{D}=$ Kemampuan Membantu Mengembangkan Sikap Positif Siswa Terhadap Belajar

E $=$ Kemampuan Melaksanakan Evaluasi Proses dan Hasil Belajar

Tabel 3. Skor Rata-Rata Hasil Supervisi Kemampuan Mengajar Guru Pada Siklus I s/d Siklus II

\begin{tabular}{clcc}
\hline No & \multicolumn{1}{c}{ Jenis Kemampuan Mengajar Guru } & Siklus I & Siklus II \\
\hline 1 & $\begin{array}{l}\text { Kemampuan mengelola kelas, waktu, dan fasilitas } \\
\text { belajar }\end{array}$ & 2,97 & 4,43 \\
\hline 2 & Kemampuan Menggunakan Strategi Pembelajaran & 2,50 & 4,35 \\
\hline 3 & Kemampuan Mengelola Interaksi Kelas & 3,00 & 4,54 \\
\hline 4 & $\begin{array}{l}\text { Kemampuan Membantu Mengembangkan Sikap } \\
\text { Positif Siswa Terhadap . Belajar }\end{array}$ & 3,74 & 4,82 \\
\hline 5 & $\begin{array}{l}\text { Kemampuan Melaksanakan Evaluasi Proses dan Ha- } \\
\text { sil Belajar }\end{array}$ & 3,75 & 4,85 \\
\hline & RATA-RATA & 3,19 & 4,60 \\
\hline
\end{tabular}

Secara ringkas hasil penelitian mendapati bahwa pertama, peningkatan kemampuan guru dalam mengajar dapat ditingkatkan melalui teknik supervisi kelas. Meskipun baru mencapai kategori cukup baik, hal demikian menegaskan bahwa teknis supervisi kelas dapat meningkatkan kemampuan guru dalam mengajar. Kedua, teknik supervisi kelas dapat mendorong kemampuan guru menjadi lebih profesional dalam mengajar.

\section{Pembahasan}

Hasil penelitian diketahui bahwa teknik supervisi kelas dapat meningkatkan kemampuan mengajar guru. Kemampuan ini merupakan wujud dari kompetensi pedagogik guru. Peningkatan kemampuan pedagogik tersebut antara lain ditunjukkan oleh kemampuan (a) mengelola kelas, waktu, dan fasilitas belajar, (b) menggunakan strategi pembelajaran, (c) mengelola interaksi 
kelas, (d) mengembangkan sikap positif siswa terhadap belajar, dan (e) melaksanakan evaluasi proses dan hasil belajar. Hal ini sejalan dengan UU Sisdiknas pasal 28 ayat 3 butir a yang menyatakan bahwa kompetensi pedagogik adalah kemapuan mengelola pembelajaran peserta didik yang meliputi pemahaman terhadap peserta didik, perancangan dan pelaksanaan pembelajaran, evaluasi hasil belajar,dan pengembangan peserta didik untuk mengaktualisasikan berbagai potensi yang dimilikinya.

Berdasarkan hasil penelitian juga diketahui bahwa teknik supervisi kelas dapat mendorong kemampuan guru menjadi lebih profesional dalam mengajar. Profesionalitas guru SD dalam melakukan proses pembelajaran menjadi tuntutan bagi seorang yang tidak bisa ditawar, terlebih untuk dapat mengantarkan siswa berhasil dalam belajar. Hal ini sejalan dengan amanat UU tentang Sisdiknas pasal 28 ayat 3 butir c yang berisi tentang kompetensi profesional guru. Kompetensi profesional guru adalah kemampuan penguasaan materi pembelajaran secara luas dan mendalam yang memungkinkan membimbing peserta didik memenuhi standar kompetensi yang ditetapkan dalam Standar Nasional Pendidikan. Pembinaan guru melalui kegiatan supervisi mutlak diperlukan agar sorang guru mampu melaksakan tugas pokok sesuai kompetensi profesionalnya.

Kusnandar (2007) menyatakan bahwa guru adalah suatu profesi yang menuntut keahlian dan memiliki kewenangan khusus dalam bidang pendidikan, pengajaran, dan pelatihan. Sebagai profesi, guru merupakan pekerjaan yang mensyaratkan kompetensi (keahlian dan kewenangan) dalam pendidikan dan pembelajaran agar dapat melaksanakan pekerjaan tersebut secara efektif dan efisien serta berhasil guna. Guru profesional adalah orang yang memiliki kemampuan dan keahlian khusus dalam bidang keguruan sehingga ia mampu melakukan tugas dan fungsinya sebagai guru dengan kemampuan maksimal.

Tugas profesional guru adalah (a) mendidik, dalam rangka menyumbangkan kepribadian; (b) mengajar, dalam rangka menyeimbangkan kemampuan berpikir, kecerdasan; dan (c) melatih, dalam rangka membina keterampilan. Untuk dapat melaksanakan tugas mengajar dengan baik guru harus memiliki kemampuan professional. Burden dan Byrd (2010) mengelompokkan 3 karakteristik utama guru profesional dalam mengajar, yaitu guru harus memiliki knowledge, skills, dan disposition. Hal senada dikemukakan Stronge and Hindman. (2004) bahwa guru berkualitas adalah guru yang antara lain (1) mampu menyampaikan materi dengan baik (verbal ability), (2) menguasai isi materi/pengetahuan (content knowledge), dan (3) memiliki pengalaman mengajar (teaching exerience).

Teknik supervisi kelas mampu meningkatkan kemampuan guru untuk menjadi sosok pendidik yang kapabel. Sardiman (1986) menjelaskan bahwa guru kapabel adalah guru yang antara lain menguasai bahan dan memahami prinsip-prinsip dan hasil penelitian pendidikan guna keperluan pengajaran. Kapabilitas guru dapat ditunjukkan oleh 3 bidang kompetensi, yaitu kognitif, sikap, dan perilaku/performance.Segi pengetahuan (kognitif), guru dituntut harus betul-betul menguasai meteri pembelajaran dan mampu mengkomunikasikan materi tersebut kepada murid. Hal demikian sejalan dengan Sudjana (1989) yang menyatakan bahwa dalam bidang kognitif, guru harus memiliki kemampuan intelektual, seperti penguasan mata pelajaran, pengetahuan cara mengajar, pengetahuan tentang belajar dan tingah laku individu dalam belajar. Burden dan Byrd (2010) juga berpendapat bahwa guru yang kompeten adalah guru yang mempunyai pengetahuan dan menguasai materi yang diajarkan, serta pengetahuan lain yang berkaitan dengan kegiatan pembelajaran (knowledge related to teaching in general, pedagogical knowledge, dan pedagogical content knowledge).

Sardiman (2006) menjelaskan bahwa proses belajar merupakan proses terjadinya saling interaksi antara orang yang mengajar (guru) dan orang yang belajar (siswa), dan masing-masing pihak berada dalam suasana belajar. Rooinjakers (dalam Mawardi, 2006) mengungkapkan bahwa ada beberapa hal penting yang seyogyanya dilakukan oleh seorang pengajar pada saat mengajar, di antaranya (1) membangun hubungan dengan peserta didik, (2) mengarahkan minat peserta didik dan menjaga perhatian mereka, (3) memberi penjelasan dan uraian tujuan pembelajaran, (4) menyebutkan pokok-pokok masalah yang 
diajarkan, (5) mengarahkan perhatian peserta didik dengan pengetahuan yang dimiliki, (6) menjelaskan struktur belajar dan mengusahakan struktur belajar bermakna, dan (7) mengajukan pertanyaan kepada peserta didik dan memberikan komentar terhadap respon peserta didik.

Rusman (2010) menyebutkan sejumlah kompetensi dasar yang harus dikuasai guru diantaranya adalah (1) menguasai bahan/materi pelajaran, (2) mengelola program pembelajaran, (3) mengelola kelas, (4) menggunakan media dan sumber belajar, (5) mengelola interaksi pembelajaran. Pelaksanaan teknik supervisi kelas dapat meningkatkan kemampuan guru dalam memilih dan menerapkan metode pembelajaran. Guru juga mengalami peningkatan kemampuan dalam berkomunikasi dan berinteraksi secara baik dengan siswa, mampu memilih dan menggunakan media sesuai dengan situasi kelas. Kemampuan ini menjadi kebutuhan seorang guru dalam mendidik. Hal ini didukung oleh pendapat Sudjana (1989) bahwa seorang guru yang profesional harus memiliki kemampuan teknis atau keterampilan seperti keterampilan mengajar, membimbing, menilai, menggunakan alat bantu pengajaran, bergaul atau berkomunikasi dengan siswa, keterampilan menumbuhkan semangat belajar para siswa, keterampilan menyusun persiapan/ perencanaan mengajar, keterampilan melaksanakan administrasi kelas.

\section{KESIMPULAN DAN SARAN}

\section{Kesimpulan}

Penerapan teknik supervisi kelas dapat meningkatkan kemampuan guru dalam mengajar, dan pada gilirannya dapat meningkatkan profesionalitas guru. Peningkatan kemampuan mengajar guru tersebut ditunjukkan oleh (a) peningkatan kemampuan mengelola kelas, (b) peningkatan kemampuan menggunakan strategi pembelajaran, (c) peningkatan kemampuan mengelola interaksi kelas, (d) peningkatan kemampuan membantu mengembangkan sikap positif siswa dan (e) peningkatan kemampuan melaksanakan evaluasi proses dan hasil belajar.

\section{Saran}

Kepala Sekolah disarankan untuk tetap mengintensifkan penggunaan teknik supervisi kelas dalam membina para guru sebagai upaya untuk meningkatkan kemampuan guru dalam mengajar dan profesionalitasnya. Guru disarankan untuk tetap memiliki kesanggupan menerima pembinaan dari kepala sekolah terutama pembinaan melalui supervisi kelas agar tercipta kompetensi dan kemampuan guru.

\section{DAFTAR RUJUKAN}

Burden, P.R. \& Byrd, D.M. 2010. Methods for Effective Teaching, Meeting the Needs of All Students. Boston: Allyn and Bacon.

Depdiknas, 2007. Petunjuk Teknis Penelitian Tindakan Sekolah (School Action Research. Jakarta: Direktorat Tenaga Kependidikan, Dirjen Peningkatan Mutu Pendidik dan Tenaga Kependidikan.

Ghafir, A \& Zuhairini, D. 1983. Metodik Khusus Pendidikan Agama Dilengkapi dengan Sistem Modul dan Permainan Simulasi. Surabaya : Usaha Nasional.

Hariwung, A.J. 1981, Supervisi Pendidikan. Jakarta: Depdikbud.

Imron, A. 1999. Pembinaan Guru di Indonesia. Jakarta: Dunia Pustaka Jaya.

Kusnandar. 2007. Guru Profesional Implementasi Kurikulum Tingkat Satuan Pendidikan (KTSP) dan Persiapan Menghadapi Sertifikasi Guru. Jakarta: PT. Raja Grafindo Persada.

Mawardi, F. 2006. Efektivitas Program Pendidikan dan Pelatihan Pegawai Pemerintah DKI Jakarta dalam Rangka Pengembangan Sumberdaya Manusia. Disertasi tidak diterbitkan, Universitas Negeri Jakarta.

Nawawi, H. 1981. Administrasi Pendidikan. Jakarta: Gunung Agung.

Pidarta M. 1992. Pemikiran Tentang Supervisi Pendidikan. Jakarta: Bumi Aksara.

Rusman, 2010. Model-model Pembelajaran, Mengembangkan Profesionalisme Guru. Jakarta: Rajawali Press 
Sahertian, P.A. 2000. Dasar dan Teknik Supervisi Pendidikan. Jakarta: Rineka Cipta.

Sardiman A.M. 1986. Interaksi dan Motivasi Belajar Mengajar. Jakarta: PT. Radja Grafindo Persada

Stronge, J.H., Tucker, P.D., \& Hindman, J.L. 2004. Handbook for Qualities of Effective Teachers.
Alexandria: Association for Supervision and Curriculum Development.

Sudjana, N. 1989. Dasar-dasar Proses Belajar Mengajar. Bandung: Sinar Baru Algensindo Offset.

Uno, H.B. 2006. Orientasi Baru dalam Psikologi Pembelajaran. Jakarta: PT Bumi Aksara. 